1 日の展示照度が比較的安定しているととを示している.

図 8 は，測定点No. 5 とNo. 12 の 9 月の 30 日間におけ る照度別累積露光時間数と照度別単位面積当りの累積光量 （照度と時間数の積の照度別の累積）を示す. 前者の累積 光量が一般の推奨值を遥かに越えていることが読み取れ る.

表 2 は, 全測定点の終日の展示照度の平均, 開館中（午 前 9 時 30 分から午後 4 時 30 分）の展示照度の平均之月別 の標準偏差の平均, 推定した年間のおおよその照射累積光 量を示す. いずれの測定点においても, 実測結果から推定 した年間のおおよその照射累積光量は, 表 1 亿示したアメ リカのIESによる值を超えているととが読み取れる。

\section{5. わりに}

美術館の展示照明の主目的は展示物（絵画）がよく鑑賞 できること，鑑賞者が気持ちのよい雾囲気にひたれるこ と, 光放射の展示物 (絵画) 一の影響を最小とすること (保護)。である

本稿では，展示照度の連続測定による実測例を示しなが ら美術館の昼光を利用した展示照明に関して述べた。空の 方式，空の大きさとその位置・方位，遮断方法などによる
展示照明のおおよその様相を類推するとともある程度可能 である。

\section{参 考 文 献}

(1) Krochmann, J., 中村洋 (訳)：美術館の照明, 照学誌, 第 63巻, 第 9 号, (昭54) 33〜40

(2) 中村洋, 沖允人 : 美術館における展示照度の連続測定（そ の1．国立西洋美術館の本館と絵画展示室，その照明設備 の概要)，(その2. 連続測定のシステムと連続測定の 例)，照学全大，93，94，（昭 62）102〜105

（3）中村洋，沖允人：美術館における展示照度の連続測定（国 立西洋美術館本館の展示照度と累積光量), 日本建築学会 大会学術講演梗概集，（昭 62）479～480

(4) Nagata, K : New Annex of the National Museum of Western art, Double Exterior Walls and Daylight Illumination, The Japan Architect 8005, (1980) 57 64

(5) Kaufman, John. E. (ed.) : IES Lighting Handbook Application Vol. 1981, Illuminating Engineering Society of North America, New York, (1981)7 29

（6）中村洋，寺沢邦彦，沖允人，他：可搬型多チャンネル㡺光 資料集録システムの概要, 日本建築学会大会学術講演梗概 集, (昭 60) $335 \sim 336$

（受付 1989年11月29日）

\begin{tabular}{|c|c|c|c|c|c|}
\hline Vol. & $\frac{n}{5}$ & ページ & 行 & 誤 & 正 \\
\hline 74 & 2 & 会告 2 & 上から1行 & $\begin{array}{l}\text { 第 } 8 \text { 回（平成 } \\
2 \text { 年) }\end{array}$ & $\begin{array}{l}\text { 第 } 8 \text { 回（平成 } \\
\text { 元年) }\end{array}$ \\
\hline 74 & 2 & 2 & 上から 1 行 & Jourual & Journal \\
\hline 74 & 2 & 2 & 上から 1 行 & Enginieering & Engineering \\
\hline 74 & 2 & 2 & 上から 2 行 & Institne & Institute \\
\hline 74 & 2 & 49 & 著者紹介 & $\begin{array}{l}\text { 势加阵考 } \\
\text { 中川靖雄君 }\end{array}$ & 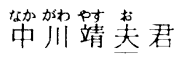 \\
\hline 74 & 2 & 50 & 著者紹介 & 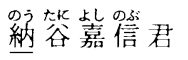 & 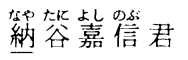 \\
\hline 74 & 3 & $\begin{array}{l}\text { データ } \\
\text { シート }\end{array}$ & №. 936 & \multicolumn{2}{|c|}{ 困 4 と困 5 の写真入れかえ } \\
\hline 74 & 3 & 表紙 & 施設名 & マンズワーク & マンズワーユ \\
\hline 74 & 3 & 1 & 下から9行 & $\begin{array}{l}\text { アメニティの } \\
\text { 㬰像上路上犯 } \\
\text { 罪 }\end{array}$ & $\begin{array}{l}ア メ ニ テ ィ の \\
\text { 丰像を求めて }\end{array}$ \\
\hline 74 & 3 & 1 & 下から 9 行 & 日原もと子 & 日原もと元 \\
\hline 74 & 3 & 1 & 下から 4 行 & 「取覚障害 & 「視覚障害 \\
\hline 74 & 3 & 28 & $\begin{array}{l}\text { 右 } \\
\text { 下から } 2 \text { 行 }\end{array}$ & $\begin{array}{l}\text { 室からの委託 } \\
\text { 研究であり, } \\
\text { 関係各位 }\end{array}$ & $\begin{array}{l}\text { 室からの委託 } \\
\text { 研究であり, } \\
\frac{\text { 侏構造計画研 }}{\text { 究所亡共同で }} \\
\frac{\text { 行なった. 関 }}{\text { 係各位 }}\end{array}$ \\
\hline
\end{tabular}

